\title{
Memórias sociais e a construção da identidade em territórios negros
}

\author{
Social memories and identity construction in black territories \\ Recuerdos sociales y construcción de la identidad en territorios negros
}

Gilmara Santos Mariosa*

\begin{abstract}
Resumo
Este artigo reflete um debate sobre a relação entre territórios negros, práticas religiosas, construção da identidade da população negra e como as memórias e representações sociais têm influência nesse processo. As práticas religiosas de matriz africana estão diretamente relacionadas com os referenciais identitários da população afrodescendente. Sabemos que essas práticas são um grande e importante legado deixado pelos africanos no Brasil para seus descendentes, no entanto as memórias dessas práticas estão sendo marcadas pelo esquecimento e as representações sociais ancoradas com práticas demoníacas relacionadas ao mal. Isso faz com que os praticantes não queiram se identificar com essas manifestações e procurem um distanciamento, enquanto os não praticantes os veem como pessoas que praticam ações que causam prejuízos. $\mathrm{O}$ resultado são atitudes de intolerância e discriminação.
\end{abstract}

Palavras-chave: Memórias. Religião afro. Território. Negros. Identidade.

\begin{abstract}
This article exposes a debate about the relationship between black territories, religious practices, identity construction of the black population and how memories and representations have influence in this process. The religious practices of African origin are directly related to the identity references of people of African descent. We know that these practices are a large and important legacy of Africans in Brazil for their offspring. However, the
\end{abstract}

\footnotetext{
Texto submetido em fevereiro de 2013 e aceito em junho de 2015.

Mestre em Psicologia Social pela Universidade do Estado do Rio de Janeiro; psicóloga pela Universidade Federal de Juiz de Fora (UFJF); foi professora da UFJF e da Universidade Presidente Antônio Carlos; foi presidente do Centro de Referência da Cultura Negra (Cerne) e coordenadora de articulação externa do Núcleo de Psicologia Social; funcionária da Câmara Municipal de Juiz de Fora, no Centro de Atenção ao Cidadão. Atua nos projetos sociais: "Diversidade: somos todos diferentes", que trata da inclusão social e combate à discriminação contra negros, idosos e pessoas com deficiência; na "Escola de cidadania", que oferece curso de formação para a cidadania para lideranças comunitárias; e na "Escola do Legislativo", que atua oferecendo capacitação externa e interna. Atuou no projeto "Cidadania Quilombola", desenvolvido em convênio entre o Cerne e a Secretaria Especial de Políticas de Promoção da Igualdade Racial do Governo Federal; no projeto "SOS Racismo", do Cerne, de atendimento multiprofissional a vítimas de discriminação racial; no "Programa de Prevenção à Criminalidade", desenvolvido em parceria entre o Elo - Inclusão e Cidadania e a Secretaria de Prevenção à Criminalidade do Governo do Estado de Minas Gerais, o programa trata do monitoramento e acompanhamento de penas alternativas e inclusão social e produtiva de egressos do Sistema Prisional. É pesquisadora do Grupo de Pesquisas Anime - Antropologia, Imaginário e Educação da UFJF. Áreas de atuação: Psicologia social e comunitária, religiões de matriz africana, memória e representações sociais, inclusão social. Endereço: Rua Pedro Botti, 380 - Passos, Juiz de Fora-MG, Brasil. CEP: 36026-290. E-mail: gilmaramariosa@yahoo.com.br.
} 
memories of these practices are being marked by forgetfulness and social representations anchored to demonic practices related to evil. This makes the practitioners no longer wish to be identify with these demonstrations and seek a distance themselves, while non practitioners see them as people who practice actions that cause harm. The results are attitudes of intolerance and discrimination.

Keywords: Memories. African religion. Territory. Black. Identity.

\section{Resumen}

Este artículo refleja un debate sobre la relación entre los territorios negros, las prácticas religiosas, la construcción de la identidad de la población negra y como los recuerdos y representaciones influyen en este proceso. Las prácticas religiosas de origen africano están directamente relacionadas con las referencias de identidad de las personas de ascendencia africana. Sabemos que estas prácticas son un legado grande e importante de los africanos en Brasil para sus descendientes, sin embargo, los recuerdos de estas prácticas están siendo marcados por representaciones sociales basadas en prácticas demoníacas relacionadas con el mal. Esto hace que los practicantes no quieran identificarse con estas manifestaciones y busquen un distanciamiento, mientras que los no practicantes los ven como personas que practican acciones que causan daño. El resultado son actitudes de intolerancia y discriminación.

Palabras-chave: Recuerdos. Religión africana. Território. Negros. Identidad.

\section{Introdução}

$\mathrm{O}$ objetivo deste artigo é discutir como a construção da identidade da população negra está relacionada aos seus territórios, e as memórias e representaçóes sociais de seus referenciais de religiosidade. Ao longo do tempo, os negros vêm perdendo seus territórios, tanto humanos e culturais como espaciais e geográficos. Essa perda se inicia na África, com o processo de colonização. Depois da diáspora, os negros no Brasil se esforçam por reconstruir seus espaços de referência, mas o processo de perda permanece. Há séculos, os negros vêm perdendo seus vínculos com o meio e os locais de origem, o que afeta diretamente sua identidade. Como podemos construir identidade sem referenciais? O que teremos para apresentar aos nossos descendentes se nossos territórios identitários são cada vez mais invadidos, deturpados, desvirtuados. Como construir subjetividades sem um território de referência? Cada vez mais terreiros, quilombos e outros territórios de forte identidade negra são perdidos. Segundo Milton Santos (2005, p. 253) território é "um lugar onde reside a 
única possibilidade de resistência aos processos perversos do mundo, dada a possibilidade real e efetiva da comunicação, logo da troca de informação, logo da construção política”.

Em Juiz de Fora, localizado na Região Sul, o bairro Dom Bosco, território afrodescendente, está perdendo seu espaço para a elite. Nesse local, a maioria da população é composta por negros. Existiu, na região, um quilombo e um cemitério de escravos. O Dom Bosco também foi formado por ex-escravos no período pósAbolição. Muitos libertos migraram da zona rural para a área urbana, e boa parte foi para o local, na época, conhecido como "Serrinha". Porém, após a construção de um shopping center, um hospital particular e também pela proximidade com a Universidade Federal, o local valorizou-se do ponto de vista imobiliário. Barreto (2010) descreve a origem e a situação do bairro:

\begin{abstract}
A formação do bairro Dom Bosco iniciou-se no ano de 1927, quando Vicente Beghelli parcelou suas terras e começou a vender os lotes "por baixo preço" aos operários. Até então, o local era denominado de Boa Vista, pois $2 / 4$ de sua área fazia parte do antigo sítio "Boa Vista", pertencente à Beghelli..."Pequeno quilombo" foi assim que se referiu o senhor Isaías (87 anos), morador do bairro Dom Bosco desde 1932, ao iniciar o diálogo com a pesquisadora. Ele relatou que, ao chegar ao bairro, havia uma presença grande de ex-escravos oriundos das fazendas de café, São Mateus e Salvaterra. Conforme esse antigo morador, as casas eram simples, feitas de sapé, o chão de terra batido e uma única estrada, chamada São Francisco, cortava o morro "Serrinha", ligando a cidade ao Distrito de São Francisco. A água era de bica e a luz de candeeiro. Com o tempo vários investimentos e construçōes foram sendo realizadas em torno do bairro: a Universidade Federal de Juiz de Fora (1960), Hospital Monte Sinai (1994), investimentos imobiliários, como a construção de prédios com fins residenciais e a obra mais recente é o Shopping Independência (2008). Outros investimentos estão em via de construção, como o Centro Médico Monte Sinai e um edifício na Avenida Independência (cuja parte da frente será voltada para os bairros São Mateus, Cascatinha e o Shopping Independência, e não haverá apartamentos de fundos, cuja vista é o bairro Dom Bosco). Essa estratégia paisagística tem uma razão de ser: não ver a pobreza, fazer de conta que ela não existe. Até porque não é apreciável uma vista de casas cujas construções precárias revelam a pobreza e miséria que muitos vivenciam na cidade e naquele bairro. (p. 205-206).
\end{abstract}

Com isso, os negros, estão sendo cada vez mais empurrados para a região mais alta, ainda não totalmente urbanizada. Em alguns trechos, não há sequer água encanada e transporte coletivo. O local é denominado "Chapadão". O Dom Bosco, portanto, é um território genuinamente negro que está sendo perdido. Podemos, de acordo com Costa (2004), entender território sob vários aspectos teóricos e práticos. Vejamos os principais: 
Enquanto um geógrafo tende a enfatizar a materialidade do território, em suas múltiplas dimensões (que deveria incluir a interação sociedade-natureza), a Ciência Política enfatiza sua construção a partir de relações de poder (na maioria das vezes, ligada à Concepção de Estado); a Economia, que prefere a noção de espaço à de território, percebe-o muitas vezes como um fator locacional ou como uma das bases da produção (enquanto força produtiva); a Antropologia destaca sua dimensão simbólica, principalmente no estudo das sociedades ditas tradicionais (mas também no tratamento do "neoliberalismo" contemporâneo); a Sociologia o enfoca a partir de sua intervenção nas relações sociais, em sentido amplo; e a Psicologia, finalmente, incorpora-o no debate sobre a construção da subjetividade ou da identidade pessoal, ampliando-o até a escala indivíduo (p. 34).

Lamentavelmente, percebemos que os moradores pouco se identificam com o território, com os lugares de memória e com as práticas de matriz africana, o que dificulta a construção de uma relação de integração com este.

\section{Memória, representações e esquecimento social}

Representações sociais são o conhecimento produzido no senso comum, com base em interações entre membros de grupos sociais. Sua principal finalidade é tornar o não familiar em familiar. Uma representação, para ser social, tem de ser sempre compartilhada. Trata-se de conceitos dinâmicos. Moscovici (1978) identifica na sociedade dois universos de pensamento. $\mathrm{O}$ universo reificado, no qual o conhecimento científico é produzido e circula o grupo de produção do saber (cientistas). Aqui a ciência e o pensamento erudito dominam. Existe um compromisso com a objetividade, com o rigor metodológico. Já os universos consensuais são o senso comum, domínio dos leigos, dos amadores. Não há compromisso com o rigor metodológico. Nesse universo, são produzidas, na interação do cotidiano, as representações sociais. É no universo consensual que são produzidas as "teorias" do senso comum. Nesse mundo, cada indivíduo é livre para elaborar conceitos, teorias que o auxiliem a melhor compreender os conceitos elaborados no universo reificado.

As representações nos servem de guia e orientação para nomearmos e definirmos os aspectos diferenciados da realidade cotidiana. Elas indicam o modo de interpretar, tomar decisões e posições diante desses aspectos do cotidiano. São fenômenos complexos e sempre ativos na vida social e "uma forma de conhecimento, socialmente elaborada e partilhada, com um objetivo prático, e que contribui para a construção de uma realidade comum" (Jodelet, 2001 , p. 22). As representações interferem nos processos sob os quais os conhecimentos são difundidos e assimilados, na formação da identidade pessoal e social, no desenvolvimento pessoal e coletivo, na expressão dos grupos e nas 
transformações sociais. Uma abordagem simultânea como produto e processo de uma determinada atividade. A realidade externa é apropriada ao pensamento e é também efetuada uma elaboração psicológica e social dessa realidade. A marca da representação é a modalidade de um pensamento no qual sua especificidade é seu caráter social (Jodelet, 2001).

Um fator de importante peso nos estudos das representações são as práticas sociais, pois são nelas que representações são criadas, de lá emergem. De acordo com Rouquette (2000), representaçōes e práticas se modificam e se transformam reciprocamente. Existe uma possibilidade de que as práticas coexistam com as representações e não de que há uma dependência casual entre uma e outra. Entendemos como práticas sociais as atividades desenvolvidas por grupos sociais no cotidiano, tais como as práticas religiosas de matriz africana.

Memórias sociais, assim como as representações sociais, são construções coletivas e compartilhadas, produzidas no cotidiano, de forma dinâmica. Estão sempre em transformação. O conceito de memória social teve sua origem com Halbwachs, discípulo de Durkheim, que o cunhou como memória coletiva. Similar ao que Durkheim fez com representações individuais e coletivas, Halbwachs também hierarquizou a memória coletiva sobre a memória individual.

Halbwachs (2004) defendia que não se deve misturar memória com história. Para o autor, a história tem compromisso com o rigor metodológico, é união de fatos que preenchem a maior parte do espaço na memória dos homens. A memória acaba onde começa a história. Ao contrário, não tem compromisso com o rigor científico nem com a verdade. A memória coletiva é a lembrança reconstruída sobre um fundamento comum de um grupo social.

Halbwachs (2004) via a memória sempre como característica de um grupo. Segundo ele, não existe memória universal, já que toda memória é construída coletivamente, dentro do grupo, e nele permanece até que o grupo se desintegre. Para Halbwachs (2004), memória é pensamento contínuo, mas não é artificial como a história. Preserva-se do passado somente o que se mantém vivo na consciência dos membros do grupo. Ela não tem limites definidos, mas somente limites irregulares entre passado e presente. Não há oposição. Ela não é fixa nem cristalizada. É dinâmica e está sempre em processo de construção. Não se pode demarcar os limites em que uma memória começa ou termina, não é possível delimitar em que momento ela deixa de existir.

Ela apresenta ao grupo um quadro de si mesmo que, sem dúvida, se desenrola no tempo, já que se trata de seu passado, mas de tal maneira que ele se reconhece dentro dessas imagens sucessivas. A memória coletiva é um quadro de analogias, e é natural que ele se convença 
que o grupo permanece, e permaneceu o mesmo, porque ela fixa sua atenção sobre o grupo, e o que mudou foram as relações ou contatos do grupo com os outros. Uma vez que o grupo é sempre o mesmo, é preciso que as mudanças sejam aparentes: as mudanças, isto é, os acontecimentos que se produzem dentro do grupo, se resolvem elas mesmas em similitudes, já que parecem ter como papel desenvolver sob diversos aspectos um conteúdo idêntico, quer dizer, os diversos traços fundamentais do próprio grupo (Halbwachs, 2004, p. 93).

Halbwachs (2004) argumentou também que a memória tem relação com a religião quando um grupo religioso necessita se apoiar sobre uma realidade perene, já que é intenção desse grupo permanecer o mesmo, resistir à mudança, mesmo que o mundo em torno dele, as instituiçôes, os hábitos e costumes mudem, mesmo que as experiências vividas se renovem. Para Halbwachs (2004), a religião vai se expressar por meio de símbolos que irão se desenvolver e se aproximar no espaço. Por isso, quando se deseja apagar a memória de deuses antigos, é necessário derrubar suas imagens e destruirmos seus templos. Dessa forma, apagamos da memória dos homens a lembrança dos cultos.

Podemos estabelecer uma relação entre essas argumentações de Halbwachs (2004) e a memória religiosa africana no Brasil. Os africanos foram arrancados de seu espaço religioso e proibidos de cultuar seus deuses. Os grupos étnicos e familiares foram separados. Tudo como uma tentativa de destruir sua memória coletiva/social e torna-los mais fracos, para serem submetidos à escravidão. Porém esse autor afirma que os deuses são onipresentes e, em qualquer lugar que para eles se ergue um altar, um novo templo, "o grupo religioso sente que cresce e se consolida” (Halbwachs, 2004, p. 164). Foi assim que os negros reconstruíram a memória religiosa em solo brasileiro.

Há esse particular no espaço religioso, de que sendo Deus onipresente, não existe região que não possa participar do mesmo caráter sagrado que esses locais privilegiados onde ele tenha se manifestado e basta que os fiéis queiram coletivamente neles comemorar este ou aquele aspecto de sua pessoa ou de seus atos, para que essas lembranças aí se prendam, com efeito, e que se possa recordá-las aí (Halbwachs, 2004, p. 165).

A memória trabalha com o que é vivido no cotidiano e no presente do grupo, levando em conta a memória de cada um que acaba se transformando na múltipla memória de todos. Por outro lado, a história tenta reconstruir o passado.

Sá (2005) cogita que a memória humana não é uma mera reprodução de experiências passadas, e sim uma forma de reconstrução dessas experiências de acordo com a realidade presente, com recursos da sociedade e da cultura. 
Quando as memórias são reconduzidas de um grupo para outro, como ocorreu com africanos e seus descendentes nascidos no Brasil, esses conteúdos são reconstruídos, o que, conforme Sá (2005), marcaria a natureza psicossocial.

Sá (2005) demarca algumas distinções em relação a algumas terminologias de memória, descrevendo variadas instâncias de memória social.

Memórias históricas orais: trata das memórias que não se baseiam em fontes documentais, mas em história oral. A preocupação não é com os registros nem com a preservação dos relatos, mas com os processos e circunstâncias em que as memórias são construídas e atualizadas pelos conjuntos sociais. Trata-se de uma memória da história que, por contar com poucos recursos documentais, privilegia recursos internos, transmitidos oralmente. Essa memória é muito comum na religiosidade afro devido à transmissão oral. Essas religiões não são baseadas em registros escritos. Tradicionalmente todo conhecimento é transmitido dos mais velhos aos mais novos por meio da oralidade. Acredita-se que a fala e o hálito dos mais velhos transmitem também o axé que acompanha o conhecimento oral e não pode ser passado pelo conteúdo escrito.

A construção da memória social dos afro-brasileiros se deu por meio da tradição oral. De acordo com Le Goff (1996), as sociedades sem escrita atribuiriam à memória uma maior liberdade criativa e não necessariamente se prenderiam à reprodução, palavra por palavra, dos fatos. Isso explicaria a recriação da tradição afro-brasileira, que se uniu a elementos católicos, indígenas, entre outros.

Memórias práticas: relaciona-se com as práticas sociais performativas, manifestas mediante ritos. De acordo com Candau (1998, citado em Sá, 2005), a transmissão é feita sem pensar. Ela está imersa na sociedade desde a infância, de forma quase automática (como fazer o sinal da cruz). Para o autor, essa memória conserva mais do que reconstrói. Ela é relevante no que compete à criação de um novo rito, pois é necessário recordar os do passado. Esse fenômeno é observado nas práticas afro, pois a cada uma que foi reconstruída no Brasil se misturam memórias práticas antigas da África.

Pelas práticas do candomblé nos rituais privados, o negro se sente africano e assim passa a pertencer a um mundo mental diferente, produzido pela memória e pelas representações sociais (Bastide, 2001).

Conforme Martins (2001, p. 64), "A África imprime suas marcas e traços históricos sobre os apagamentos incompletos da diáspora, inscrevendo-se nos palimpsestos que, em inúmeros processos, transcriam e performam sua presença nas Américas". Sobre o esquecimento social se inscreve a nova linguagem da África revivida e reconstruída na realidade brasileira com as possibilidades que 
o nosso universo cultural a ela proporciona, pela ação ritual. De acordo com a autora, em territórios sagrados, África e Europa se aproximam, esbarram-se, mas jamais se fundem ou se perdem uma na outra, como no caso dos reinados negros dos congados, que se reconhecem como católicos, mas seus ritos remetem à África.

Por meio de representações, são estabelecidos canais de negociação entre arquivos culturais africanos e europeus. Há uma apropriação espacial de territórios simbólicos, que se transformam para garantir, pela metamorfose, a sobrevivência das formas primárias ameaçadas de extinção. Martins (2001) relata que aqui o tempo não é linear, o rito abole o tempo nessa concepção e o transforma em tempo vivido, atraindo passado e futuro. A ação é restaurada e assim reconstruída, renovada, com novos elementos. A palavra, o corpo, a dança, a roupa, a comida, tudo é revivido e reconstruído nesse rito.

As diversas denominações e classificações da memória social e das representaçõos sociais têm relação direta com as reconstruçōes, ressignificações e atribuições de valores das religiōes de matriz africana. As lembranças que se têm dessas religiōes são provenientes dos conteúdos transmitidos pelos antepassados, pelo conhecimento que se adquire da sociedade contemporânea, acrescidos de novos conceitos, novas representações reelaboradas e reconstruídas.

Ao lado das lembranças da memória social dos africanos, encontramos também o esquecimento. Para reconstruir, foi preciso esquecer, já que o retorno à África não era possível. Era necessário refazer toda uma cultura e todo um culto religioso em uma terra estranha, hostil, inóspita.

$\mathrm{O}$ ato de contar, de rememorar faz com que esta terra perdida se constitua em um território virtual, de imaginação, ou ilusão, permitindo sua atualização e cada ato de contar e descrever. A nostalgia é uma experiência humana que permite lidar com o que se perdeu de maneira irremediável no campo da realidade, sem a inexorabilidade da destruição da lembrança. A terra perdida é reconstruída pelos conteúdos da memória, situando-se no território da interpretação; naquilo que transcende o sujeito (Castro, 2005, p. 2).

Sob o ponto de vista da Psicologia social, a memória social é fonte de compartilhamentos e interaçôes, transcendendo um corte disciplinar e necessariamente tendo que dialogar com outras ciências humanas, para a possibilidade dessa abordagem e para a maior compreensão do fenômeno. Lembranças e esquecimentos estão, dessa maneira, estreitamente unidos nesse processo. Conforme Castro (2005), os fatos sociais e acontecimentos políticos que serão lembrados ou esquecidos em nossa sociedade estarão diretamente ligados a atribuição de valores que se dará ao fato, que sofre um desdobramento 
no campo representacional, cultural e ideológico de um grupo. Isso, porém, não quer dizer que a memória seja estática. Ela é ativa e dinâmica e, assim, esquecimento e lembrança também estão relacionados de forma ativa, dinâmica, sempre em transformação, submetidos à ação do tempo e das interações sociais.

$\mathrm{Na}$ construção semântica da narrativa entre lembrança e esquecimento de um fato social o que realmente importa é a atribuição de valores, diz Castro (2005). A história passa a atuar como colaboradora da memória e não mais como aquela que dela desconfia, auxiliando agora no entendimento e na compreensão dos fenômenos psicossociais envolvidos na construção da memória social. Ciência e história ajudam também na compreensão do que determinará, por meio de uma dinâmica social, o que será lembrado e o que será esquecido.

Castro (2005) aponta que tratar o "esquecimento" como falta, como ausência de memória, como indicador de déficit cognitivo, na verdade, é abordar um tema de uma maneira limitada. Interessa aos estudiosos desenvolver reflexóes a respeito desse esquecimento, não como vazio ou lacuna de memória, mas como espaço cheio de significados representacionais. Esquecimento é definido então como uma construção social, compartilhada, estabelecida pelas relações interpessoais em determinados grupos sociais. Castro (2005) afirma que a memória social será reconstruída por um misto entre lembrança e esquecimento que, de forma dinâmica e ativa, determinará a reconstrução através do tempo e das interações sociais. As abordagens da memória sobre esse aspecto levam em conta a experiência do sujeito, sua história de vida, com as situaçôes coletivas. Sabemos que os fatos que o indivíduo vai lembrar ou esquecer estarão ligados, em primeiro lugar, aos que ele teve alguma participação direta ou indireta. São os casos em que será estabelecida uma ancoragem do acontecimento social na experiência individual do sujeito. Também os fatos que o sujeito não vivenciou farão parte da sua memória por meio de monumentos, documentos ou mesmo da história oral de seus antepassados, o que é mais comum nas religiōes de matriz africana.

A realidade contemporânea nos coloca em situações na quais um excesso de informaçôes nos dificulta selecionar o que vai ser lembrado ou esquecido, observa Castro (2005). Guardam-se informações em excesso e se perde a noção, com o tempo, do que se guardou. A realidade contemporânea é fluida e volátil. Tudo se perde com rapidez e é substituído por algo "novo" e descartável. As memórias tradicionais vão se perdendo em meio a esse universo de falsas memórias que, muitas vezes, são-nos impostas por um poder superior que quer decidir o que é importante que lembremos e o que é importante que esqueçamos. Essa foi uma das imposições dos brancos europeus aos africanos no Brasil. Mas os acontecimentos não se deram de forma tão determinada, como sabemos. 
Castro (2005) revela que há uma sobrevaloração do presente, provocando um desprezo pelo passado. Um esquecimento permanente é o que se quer produzir. De acordo com May (1992), a memória depende principalmente do mito. Ele diz muito para a memória do indivíduo, pois fatos ocorrem e são, na verdade, acrescidos de fantasia. Partindo disso, memórias e mitos são construídos. A pessoa ou grupo que constrói um mito reconstrói o acontecimento, moldando e acrescentado cor e detalhes.

\section{A matriz africana e a intolerância religiosa}

Quando estudamos religiôes de matriz africana, percebemos várias facetas. Uma diz respeito à beleza e ao encantamento delas em si e de seus praticantes. Outra é a discriminação sofrida pela sociedade por não serem práticas necessariamente originadas no cristianismo (já que a África pré-colonial não era cristã) não serem maniqueístas e representarem valores diferenciados. Identificamos principalmente representações e memórias sobre candomblé, umbanda e benzedeiras. Apesar de as duas últimas serem sincretizadas com aspectos do cristianismo, as marcas das matrizes africanas estão presentes e podem ser identificadas.

De acordo com Mariosa (2009), em pesquisa realizada no bairro Dom Bosco, em Juiz de Fora, escolhido em razão das características de territorialidade e população afrodescendente, a maioria dos entrevistados (todos negros) se identificam como católicos. Contudo, ao longo das entrevistas, pudemos perceber que uma parcela pratica ou já praticou as religiōes de matriz africana. Apesar dessas constatações, observamos ser comum as pessoas não se apresentarem como praticantes de religióes afro-brasileiras. A população em geral tem receio de se autoidentificar como frequentador de candomblé e umbanda, temendo ser discriminada. Os sujeitos que se identificaram como evangélicos, quando tomaram conhecimento do conteúdo da pesquisa, recusaram-se a participar. Isso ocorreu, talvez, devido às representações sociais de demonização atribuídas às religiōes afro.

Há o sentimento de vergonha e o medo de represália. Portanto, quando são questionados sobre qual é a sua religião, os entrevistados praticantes hesitam em responder. Os que não são praticantes, em sua maioria, têm medo, acreditam que os que lá estão, de alguma forma, praticam o mal, fazem feitiços com intenção de prejudicar os outros. Alguns têm uma fantasia de contágio, acreditam que o mal pode ser transmitido até pela comida que vem da mão de um "macumbeiro", ou mesmo temem estar perto ou conversar, como se somente a presença fosse irradiadora de um poder maligno. Constatamos que os praticantes mentem para não serem reconhecidos como alguém que carrega esse peso. $\mathrm{Na}$ verdade, aqui 
os referenciais de africanidade religiosa contribuem para uma visão pejorativa daqueles que, com eles, têm contato direto ou indireto. Por isso a declaração de ser católico ou espírita é mais socialmente aceita.

O temor da dor da rejeição revela-se na mentira e na omissão, tentativa de disfarçar a verdade, para fazer parte do mundo dos aceitos. A rejeição, por vezes, transforma-se em agressão e, em outras, em energia para o combate à exclusão e à discriminação. No caso da omissão, transforma-se em resignação e em conformismo. Ocultar, de alguma forma, a verdadeira opção religiosa é uma forma de mascarar a realidade e responder a uma pressão social. É o que Piza (2005) chama de processo de negridade, termo utilizado pelo movimento negro das décadas de 1920 e 1930, que reivindica a inclusão do negro na sociedade branca, por meio da negação de sua origem e por um comportamento ditado e aprovado por brancos. Negridade refere-se a "parecer" branco para ser aceito entre brancos, o que explica a necessidade de negação das origens africanas, tais como a religiosidade.

Para o sujeito negro oprimido, os indivíduos brancos, diversos em suas efetivas realidades psíquicas, econômicas, sociais e culturais, ganham uma feição ímpar, uniforme e universal: a brancura. A brancura detém o olhar do negro antes que ele penetre na falha do branco [...] Funciona como um pré-dado, como uma essência que antecede a existência [...] Vítima dos efeitos dessa alienação, pouco importa, então ao sujeito negro que o branco real, enquanto indivíduo ou grupo venha a fazer, sentir ou pensar [...] A brancura transcende o branco. Eles - indivíduo, povo, nação, ou estado ranço - pode "enegrecer-se". Ela, a brancura, permanece branca. Nada pode macular esta brancura que, a ferro e fogo, cravou-se na consciência negra como símbolo de pureza artística; nobreza estética, majestade moral; sabedoria científica etc. O belo, o bom, o justo e o verdadeiro são brancos. O branco é, foi e continua sendo a manifestação do Espírito, da Ideia, da Razão. O branco, a brancura, são únicos artífices e legítimos herdeiros do progresso e desenvolvimento do homem. Eles são a cultura, a civilização, em uma palavra, a "humanidade". O racismo esconde assim seu verdadeiro rosto. Pela repressão ou persuasão, leva o sujeito negro a desejar, invejar e projetar um futuro identificatório antagônico em relação à realidade de seu corpo e de sua história étnica pessoal (Costa, 1983, p. 4).

A negação é a forma que as pessoas encontram de se defender de agressões e outros comportamentos hostis. Quando um problema parece de difícil solução os seres humanos tendem a fingir que eles não existem. Essa, às vezes, é a solução encontrada. Negam-se as origens, nega-se ancestralidade, aquilo do qual não se gosta ou se pensa que os outros não vão gostar. Esse é um processo psicossocial de adoecimento. 
Grande parte das manifestações racistas cotidianas são clandestinas e mal dimensionadas. Os legados cumulativos da discriminação, privilégios para uns, déficits para outros, bem como as desigualdades raciais que saltam aos olhos, são explicadas e, o que é pior, frequentemente "aceitas", através de chavões que nenhuma lógica sustentaria, mas que possibilitam o não enfrentamento dos conflitos e a manutenção do sistema de privilégios. Assim, ainda que os impactos do racismo se manifestem de modo diverso na vida de negros e brancos, não é incomum a tendência a fugir ou esquecer a condição de discriminado e de discriminador (Bento, 2002, p. 147).

Por meio da fuga, não é preciso admitir o privilégio, nem o contrário. Dessa forma, oculta-se o fato de que o lugar de uns é designado por outros que, assim, acabam por se estabelecer num lugar confortável. Se o lugar predeterminado é aceito, o outro colabora, de certa forma, para que assim permaneça. Se uns querem mudar de lugar, vem o sofrimento resultante da pressão contrária. Há uma efetiva tentativa de fazer com que os primeiros se sintam como se estivessem tirando lugar dos outros, estabelecido não por direito, mas por privilégio. $\mathrm{O}$ privilegiado deduz que está lugar que sempre foi seu e ainda se respalda no discurso do mérito. Contudo desconhece ou ignora que, para ele estar lá, outros foram tirados dali ou são impedidos de entrar.

Mudar, por exemplo, no sentido de reconhecer que muitas vezes aquilo que orgulhosamente classificamos como mérito, está na verdade marcado também pelo privilégio, ou seja, numa sociedade racializada, ser branco sempre faz diferença. Dito de outra maneira, negros nas mesmas condições que brancos não costumam ter as mesmas oportunidades, os mesmos tratamentos (Bento, 2002, p. 148).

Abrir mão do espaço é algo que muitos se recusam a sequer considerar. Preferem usar o argumento da neutralidade para se esconder.

Do ponto de vista psicológico, é um espaço confortável, porque nele os sujeitos se reconhecem pela neutralidade racial na qual vivem, ainda que percebam a racialidade do "outro"; eu existo inteiramente neutro, enquanto representante da minha não racialidade. Mas, se considerarmos o trajeto de dentro para fora, isto não significa negar a branquidade, mas afirmá-la ou deixar-se afirmar por ela, já que ela é o modelo de humanidade que se carrega desde a mais tenra infância. De fora para dentro, a branquidade entra pelos sentidos como valor intrínseco da minha condição humana. Ela é um passaporte para qualquer espaço social. Ainda que a classe e o gênero possam limitar certas aspirações, a branquidade pode ser a garantia de um outro status social, ao qual os "diferentes" não têm acesso. É esta não racialidade que garante os privilégios, mesmo que sejam poucos, com os quais se pode conseguir afirmação psicológica e social para atravessar, pelo menos em parte, barreiras de classe e, com um pouco mais de esforço, as de gênero (Piza, 2005, p. 4). 
A intolerância religiosa presente no cotidiano faz com que os seguidores das religiōes de matriz africana sejam vítimas de várias modalidades de violência. Para escapar da discriminação, os adeptos se utilizam de estratégias para parecerem invisíveis, tal como nos relatou Caputo (2012) em sua pesquisa sobre como são tratadas as crianças do candomblé na escola. Duas irmãs revelaram que, em sua comunidade, frequentaram a Igreja Católica por um longo tempo para disfarçar: "Ia às missas, fiz até Primeira Comunhão. Queria que as pessoas pensassem que eu era católica, talvez parassem de zoar. E eu também queria ter mais amigas" (Caputo, 2012, p. 206). A ocultação de si mesmos nas sombras da invisibilidade acaba por ser uma solução para serem aceitas. Solução que também agrada aos dominadores, que assim permanecem fingindo que tais categorias não existem e, quando elas emergem, empurram-nas para o oceano da invisibilidade, com ações hostis diretas ou indiretas. Outro caso foi o de Jailson, que revelou que nunca sentiu preconceito, "'A não ser aquele preconceito normal'. 'Como assim preconceito normal?', pergunto. 'De me chamarem de macumbeiro e de acharem que macumbeiro sempre está pronto para fazer mal a alguém”' (Caputo, 2012, p. 201). A experiência da discriminação e da humilhação está tão introjetada em Jailson que ele já toma esse fato como "normal". Ele também revela que não fala sua religião e, se alguém lhe pergunta, diz que é católico, esconde-se no silêncio, para fugir da humilhação. Vemos, mais uma vez, que as vítimas da discriminação têm plena consciência do motivo. Elas são categóricas ao associarem rejeição de sua religião e de suas culturas ao fato de serem negras e praticarem uma religião afrodescendente. Essa identificação ocorre mesmo quando a associação raçareligião é feita de forma velada, disfarçada.

Mariosa (2009) observou a presença de lembranças relacionadas às práticas de origem africana, entretanto, com ênfase maior se dá na atribuição de valor negativo, presente quando os entrevistados identificam "feitiçaria para o mal" como uma prática religiosa de origem afra. Sá, Belo e Jodelet (1998) afirmam que a feitiçaria para o mal tem alguma ligação com as representações sobre as condições de eficácia das práticas de cura na umbanda.

Na pesquisa de Mariosa (2009), algumas entidades relacionadas às práticas de origem afra, como Exu e Pombajira, são vinculadas ao mal, ancoradas com o demônio. Verger (1997) afirma que Exu gosta de suscitar discussóes e disputas, de provocar acidentes e calamidades públicas e privadas, é astucioso, grosseiro, vaidoso e indecente. Essas características não agradaram aos padres do Período Colonial, que o conceituaram como representação do demônio e atribuíram a ele tudo o que é maldade, perversidade e oposição à bondade.

Todos esses aspectos de associação das práticas religiosas de matriz africana ao mal, ao demônio, dificultam os processos de representação positiva e nos alertam 
para a necessidade de enfrentamento dessa situação. A verdadeira mudança somente vai ocorrer quando admitirmos que existem, sim, as diferenças e as desigualdades. Somente então estaremos, de fato, caminhando na direção de uma sociedade mais igualitária.

\section{A memória na construção da identidade}

Quando buscamos reconstruir a memória das religiões de matriz africana em Juiz de Fora, observamos as marcas do esquecimento. A maioria dos pesquisadores alega não haver registros e esse tema ser muito difuso e pauta para futuros estudos. Isso porque os entrevistados geralmente se declaram como católicos. Essa é mais uma consequência do processo de branqueamento dos valores e tradições dos negros que ficam esquecidos. É o que observamos em Tavares e Floriano (2003), quando afirmam que a história da tradição afro-brasileira da Zona da Mata mineira, particularmente de Juiz de Fora, ainda está por ser contada, pois existem muitas lacunas sobre a verdadeira participação da religiosidade africana na história e nas memórias regionais. As poucas informações registradas em estudos atuais foram obtidas por meio de depoimentos de informantes, colhidos por pesquisadores.

No caso de Juiz de Fora, o impacto da Abolição não levou os negros aos centros urbanos, que ficaram a cargo dos imigrantes. Somente com a decadência das lavouras de café, no período de 1920, é que começaram a fluir em direção à cidade, em busca de emprego e moradia. No entanto, como esse movimento ocorreu tardiamente, os centros urbanos já estavam ocupados pelos imigrantes e não ofereciam mais espaço para a mão de obra e moradia dos negros, que partiram, então, em direção às periferias. Esse fato levou à formação de bairros inteiramente de pessoas negras, como o São Benedito (antigo Arado) e Dom Bosco (antiga Serrinha). Essas regiões não tinham a mínima infraestrutura, como acesso a rede de água, esgoto, iluminação pública, etc.

Tavares e Floriano (2003), em pesquisa realizada sobre a tradição afro-brasileira em Juiz de Fora, mostraram que a memória é bastante difusa e pouco conhecida. De acordo com depoimento de informantes, essa tradição é acentuada pela antiguidade da umbanda. Alguns a associam a uma continuação de tradições anteriores, como cabula ou canjerê. Tavares e Floriano (2003) ressaltaram que o canjerê seria a prática mais antiga, atribuindo a Dona Mindoca sua fundação na cidade. Há, contudo, aqueles que dizem que a prática no centro de Dona Mindoca era a umbanda. Mesmo não havendo consenso entre o que se praticava no centro, há acordo sobre o caráter precursor de Dona Mindoca. A falecida Almerinda, mais conhecida como Dona Mindoca, era uma mulher branca, 
nascida em cidade próxima, falecida na década de 1940. De acordo com os informantes de Tavares e Floriano (2003), teria fundado a casa mais antiga de Juiz de Fora, no início do século XX. O seu centro ainda existe e está em funcionamento.

Porém chama a atenção o fato de esses informantes identificarem uma mulher branca como precursora das tradiçōes afro-brasileiras num espaço que chegou a abrigar o maior contingente de negros do País. Contudo, em pesquisa realizada por França (2009), por meio de fontes do Jornal do Comércio, de 1906, a respeito do discurso jornalístico sobre os canjerês em Juiz de Fora, surgiram dados da presença de casas de Canjerês na cidade. Um jornalista teria visitado uma casa de Canjerê na qual o chefe era um negro, ex-escravo, chamado de Tio Pedro. Esse dado coloca em dúvida o relato de que a fundadora da primeira casa de culto afro da cidade seja uma mulher branca vinda de fora do Município. É nesse sentido que Carvalho (2005) argumenta:

[...] o discurso da antropofagia de Oswald de Andrade. Esse discurso antropofágico colocou a centralidade e o prestígio da ação simbólica em quem controla os meios de difusão do produto cultural resultante da suposta síntese estética nacional. Quem define o "só me interessa o que não é meu”? Segundo o credo antropofágico, eu posso ir aonde quiser e canibalizar o que quiser, em nome da minha arte, da minha música, da minha literatura, da minha pintura, do meu teatro. Posso retirar qualquer expressão simbólica do seu contexto e fazer dela o que julgar melhor, já que somos todos antropófagos (p. 5).

Carvalho (2005) descreveu como esse processo de apropriação, que ele denomina de antropofagia, desenvolve-se socialmente em relação às religiōes de matriz africana.

Por muitas décadas do século XX, então no contexto da censura, da negação e da desqualificação racista da população negra, ficou marcada a constituição da arte sagrada afro-brasileira, que vivia numa espécie de mundo paralelo, apenas com pequenos pontos de contato com o mundo branco poderoso (e foram justamente os pesquisadores os poucos elos entre esses universos). De repente, nos anos noventa, com uma intensificação inusitada da sociedade do espetáculo, ocorreu uma virada radical no desejo da etnia branca. Tradiçōes culturais afro-brasileiras, que antes não interessavam, passaram a ser deglutidas, absorvidas e canibalizadas amplamente, para fins de entretenimento. Foi como se os brancos de classe média sentissem subitamente um cansaço de sua visão de mundo ocidentalizada, a qual necessitou urgentemente ser revitalizada através da visão de mundo sagrada afro-brasileira (p. 9). 
Os referenciais de África são sempre atribuídos com negatividade pelo sistema branco dominante. Em se tratando dos relacionados à religiosidade, geralmente as atribuições são de algo ruim, relacionado ao mal ou algo que remete ao ignorante ou aos que são primitivos. Percebemos aí duas faces da inferiorização das tradições africanas. Ou são demonizadas, devido à diferença de suas práticas com as práticas cristãs, tratadas como feitiçarias para invocar o mal, práticas que trazem prejuízos às pessoas e culto ao demônio. Ou são inferiorizadas no sentido de que quem pratica essas crenças religiosas são pessoas ignorantes, sem instrução, sem conhecimento erudito. Há, ainda, aqueles que atribuem aos praticantes desses cultos transtornos psiquiátricas, tais como psicose ou histeria.

Aspectos culturais dos negros desde sempre foram utilizados para justificar sua inferioridade em relação aos brancos e até mesmo a escravidão, como podemos constatar na declaração de Rodrigues (2004), na qual afirmava a inferioridade até mesmo por características físicas e culturais. $\mathrm{O}$ autor acreditava que os negros jamais alcançariam o estágio de evolução dos brancos europeus, pois, além de estarem muito atrasados, evoluíam de forma muito lenta.

Observamos que as práticas de cura são apropriadas pelo branco quando há interesse. Há muita valorização e modismo em torno de técnicas usadas, como banhos medicinais, chás, unguentos, florais, e outras que trabalham com manipulação de ervas e energias. Essas técnicas, apesar de criticadas pela ciência acadêmica, no sentido de dúvidas com respeito a sua eficácia, são socialmente aceitas. Mas quando são associadas a cultos de matriz africana, são relegados ao status de charlatanismo ou coisa pior. De acordo com Bento (2002, p. 153), "O processo de naturalização do preconceito e do estereótipo em nossa subjetividade, que torna a todos, voluntária ou involuntariamente, cúmplices de sua perpetuação".

\section{Considerações finais}

Podemos vislumbrar como é possível identificar como as pessoas negras crescem e constroem suas identidades. Habitamos em um universo onde nossos referenciais de ancestralidade são quase todos associados a fatores negativos. No qual o espelho reflete ora o que somos, ora o que queremos ser. A dura realidade é que, em boa parte das vezes, os dois reflexos são completamente diferentes. Os lugares sociais do negro são demarcados, e os que ousam transgredir são duramente reprimidos. Alguns, para conciliar, se embranquecem e fazem o jogo social, associando-se ao mais forte, como o ditado antigo: "se não se pode vencêlos, junte-se a eles”. Outros se resignam ao lugar que lhes é relegado. Há ainda aqueles que ousam transcender e ocupar os lugares que são socialmente vistos 
como já ocupados pelos brancos. Às vezes, pagam um alto preço por isso, mas têm a satisfação de dever cumprido. Resta-nos decidir de que lado vamos estar. Onde nos localizamos nesse território social tão demarcado? Vamos ocupar nosso território ou nos contentar com os espaços que nos são relegados? 


\section{Referências}

Barreto, A. C. J. (2010). O lugar dos negros pobres na cidade: estudo na área de risco do Bairro Dom Bosco. Libertas, 10(2), 188-215. Recuperado a partir de https://libertas.ufjf.emnuvens.com.br/libertas/article/view/1879/1327.

Bastide, R. (2001). O candomblé da Bahia. São Paulo: Companhia das Letras.

Bento, M. A. S. (2002). Branquitude: o lado oculto do discurso sobre o negro. In I. Carone \& M. A. S. Bento (Orgs.), Psicologia social do racismo. (pp. 147162). Petrópolis: Vozes.

Caputo, S. G. (2012). Educação nos terreiros: e como a escola se relaciona com crianças de candomblé. Rio de Janeiro: Pallas.

Carvalho, J. J. (2005). As artes sagradas afro-brasileiras e a preservação da natureza. Série Antropologia, 381, 1-20. Recuperado a partir de http://dan. unb.br/images/doc/Serie381empdf.pdf.

Castro, R. V. (2005). Esquecimento social: ensaios sobre a contemporaneidade. Psicologia Clínica, 17(1), 111-122.

Costa, J. F. (1983). Prefácio. In: N. S. Souza, Tornar-se negro: as vicissitudes da identidade do negro brasileiro em ascensão social. (pp. 1-16). Rio de Janeiro: Graal.

Costa, R. H. (2004). O mito da desterritorialização: do "fim dos territórios" à multiterritorialidade. Rio de Janeiro: Bertrand Brasil.

França, D. S. S. (2009). Nas manchetes dos jornais: o olhar jornalístico sobre os canjerês na primeira década do século XXI. Revista Sacrilegens, 5(1), 23-58. Recuperado a partir de http://www.ufff.br/sacrilegens/files/2009/06/5-3.pdf.

Halbwachs, M. (2004). A memória coletiva. São Paulo: Centauro.

Jodelet, D. (2001). Representações sociais: um domínio em expansão. In D. Jodelet (Org.), As representaçôes sociais. (pp. 17-44). Rio de Janeiro: Eduerj.

Le Goff, J. (1996). História e memória. Campinas: Edunicamp.

Mariosa, G. S. (2009). Negras memórias da princesa de Minas: memórias e representaçôes sociais de práticas religiosas de matriz africana. Juiz de Fora: Funalfa. 
Martins, L. M. (2001). A oralitude da memória. In M. N. S. Fonseca, Brasil afro-brasileiro. (pp. 61-86). Belo Horizonte: Autêntica.

May, R. (1992). A procura do mito. São Paulo: Manole.

Moscovici, S. (1978). A representação social da psicanálise. Rio de Janeiro: Zahar.

Piza, E. (2005). Adolescência e racismo: uma breve reflexão. In Anais do 1 Simpósio Internacional do Adolescente: São Paulo: Faculdade de Educação da Universidade de São Paulo. Recuperado a partir http://www.proceedings.scielo. br/scielo.php?pid=MSC0000000082005000100022\&script=sci_arttext.

Rodrigues, R. N. (2004). Os africanos no Brasil. Brasília: EdUNB.

Rouquette, M. L. (2000). Representações e práticas sociais: alguns elementos teóricos. In A. S. P. Moreira \& D. C. Oliveira (Orgs.), Estudos interdisciplinares de representação social. (pp. 39-46). Goiânia: AB.

Sá, C. P. (2005). As memórias da memória social. In C. P. Sá, Memória, imaginário e representação social. (pp. 63-86). Rio de Janeiro: Museu da República.

Sá, C. P., Bello, R. A \& Jodelet, D. (1998). Condições de eficácia das práticas de cura da umbanda: a representação dos praticantes no Rio de Janeiro. Psicologia \& Sociedade, 10(1), 128-144.

Santos, M. (2005). O retorno do território. OSAL: Observatório Social de América Latina [on-line], 6(16), 251-261. Recuperado a partir de http:// bibliotecavirtual.clacso.org.ar/ar/libros/osal/osal16/D16Santos.pdf.

Tavares, F. R. G. \& Floriano, M. G. (2003). Do canjerê ao candomblé: notas sobre a tradição afro-brasileira em Juiz de fora. In F. R. G. Tavares \& M. A. Camurça (Orgs.), Minas das devoçôes: diversidade religiosa em Juiz de Fora. (pp. 15-40). Juiz de Fora: EDUFJF.

Verger, P. (1997). Orixás. Salvador: Corrupio. 